\title{
Dictogloss as a Technique to Raise EFL College Students' Knowledge of Grammar, Writing and the Comprehension of Meaning
}

\author{
Liqaa Habeb Al-Obaydi ${ }^{1} \&$ Fatima Raheem Al-Mosawi ${ }^{2}$ \\ ${ }^{1}$ Department of English, College of Education for Human Sciences, University of Diyala, Diyala, Iraq \\ ${ }^{2}$ Department of English, College for Basic Education, Mesan University, Mesan, Iraq \\ Correspondence: Department of English, College of Education for Human Sciences, University of Diyala, \\ Diyala, Iraq. E-mail: liqaahabeb@yahoo.com
}

\author{
Received: September 5, 2018 Accepted: October 2, 2018 Online Published: December 29, 2018 \\ doi:10.5539/ijel.v9n1p293 URL: https://doi.org/10.5539/ijel.v9n1p293
}

\begin{abstract}
Dictogloss is a classroom activity where all the four skills work together. The present study is an experimental one where a group of twelve students was taught by the researchers. The researchers train students to use dictogloss technique for twelve lectures. In each lecture, they used a new authentic text with a new focus on a specific role of grammar. The study aims at; finding out the impact of using dictogloss technique on Iraqi EFL college students' knowledge of grammar, determining the impact of using dictogloss technique on Iraqi EFL college students' improvement of writing, determining if there is any impact of using dictogloss technique on EFL college student's comprehension of meaning and determining students' attitudes toward using dictogloss in English language teaching. Four measurement tools were used in this study; an achievement test, a reflection sheet used at the end of each lecture, a questionnaire, and in addition to the teacher's daily observation. Final results of the study clarify that there is a positive impact of dictogloss technique on the three variables in addition to the positive attitudes of students towards using dictogloss in English language teaching. So, the hypotheses of the study are rejected.
\end{abstract}

Keywords: dictogloss, grammar knowledge, writing

\section{Introduction}

\subsection{Dictogloss}

Dictogloss is an integrated skills technique of teaching based on the ideas of dictation. Traditional Dictation is "where you read a text aloud and the learners must write it down accurately" (Scrivener, 2011, p. 362). It is as stated by Johnson and Johnson (1999, p. 97) "a technique associated with traditional accuracy-focused methodology. The teacher read a text aloud right through and then with pauses, while students wrote down exactly what was said". As this technique abandoned by the trends of communicative methodology, other variations that required the integration of the four skills appeared (ibid). This includes dictogloss, cloze dictation, picture dictation, keywords dictation, collocation dictation, wall dictation, and the wild dictation.

Dictogloss was presented in 1990 by Wajnryb as a method for teaching grammar dictation. It occurs where "the students listen twice to a short talk or a reading on appropriate content. The first time listen to the main idea then the second time listen to the details" (Freeman \& Anderson, 2011, p. 142). Then, writing notes for about three minutes. During this period, "it is important that students get a good, quite time to do this" (Scrivener, 2011, p. 364). Reconstructing the main ideas of it and finally, correcting the grammar and writing mistakes which lead students to reflect on their own work. Among all these activities, the insertion of cooperative learning exists. The students work in groups or in peer work to finish the task.

Many studies tackled the use of dictogloss in language teaching. Dewi (2017) assures that students' competence of grammar was improved through collaborative writing dictogloss. She adds that most students agree on the interesting way of dictogloss in teaching grammar. The use of dictogloss in teaching has many merits as recommended by Stewart et al. (2014, p. 12) "Dictogloss procedures are practical, yet flexible enough to account for the needs, interests, and learning preferences of each learner. But more than that, the dictogloss activities allow English learners to be active and reflective during the learning process". They add that "Instead of reinforcing a linear approach to learning (i.e., input-comprehension-output), the dictogloss procedures illustrate a 
learning approach where students have opportunities to integrate reading, writing, listening, and speaking skills through social interaction". Smith (2012) adds that dictogloss technique effects directly the independence of students as they become autonomous learners due to the development of their communicative competence. On the same way, students' authentic communication and interaction is improved significantly as stated by Mackenzie (2011) who explained how the collaboration of the students can provide them with opportunities to use a language.

\subsection{Teaching Grammar}

The matter of teaching grammar has been under discussion for a long period. While some teachers encourage the classical methods of teaching grammar, in which they consider grammar as a set of rules and forms being under explanation and drilling, others are being against this way suggesting to expose students to a language in its written and oral forms and not to teach overt rules of grammar at all. Three main methods of grammar teaching are being under discussion for a long time; deductive, inductive, and interactive.

Deductive grammar teaching requires teachers to present direct explanation of grammar rules. Lin (2010, p. 20) identified some characteristics of it stating that it is a rule-based teaching and it depends on the presentation and explanation of rules. Studying grammar deductively according to Freeman and Anderson (2011, p. 19) occurs when the students "are given the grammar rules and examples and told to memorize them and then are asked to apply the rules to other examples. They also learn grammatical paradigms such as verb conjugations".

Inductive teaching of grammar refers to providing students with "various language forms and leaving the learners to discover or induce rules and generalizations" (Brown, 2001, p. 365). Freeman and Anderson (2011, p. 240) clarify that "inductive grammar teaching happen when the teacher gives students examples with a particular grammar structure. The students figure out the rule".

Johnson and Johnson (1999, p. 147) clarify that "the deductive and inductive approaches have not always been violently opposed". They add that "the sniping between the two camps involved, which may be characterized as a grammar-translation and direct method respectively. It is noteworthy that there was little discussion of aims, much more of the best way to teach".

Teaching grammar in the context of writing as tackled by this study comes as opposed to teaching grammar in a single sentence. It deals with teaching grammar by using several sentences that construct a specific context or a situation. Context of writing as depended by this study means a piece of writing or discourse that helps to make the meaning clear. This way of teaching grammar draws attention on grammar as a choice giving opportunity to students to use it in a particular context of language (Carter et al., 2000, p. vii).

\subsection{The Statement of the Problem}

Using dictogloss technique for teaching grammar recommended by many writers. It is originally designed to provide an alternative way to traditional grammar teaching (Wajnryb, 1990). Nunan (2001, p. 306) clarifies that it is "a procedure used for teaching grammatical structures in context". Scrivener (2011, p. 364) assures that "The text could include an example of a grammatical item".

It is important to mention that the use of contexts in teaching grammar is very crucial as it provides students with enough practicing that needed in acquiring the rules of grammar as opposed to the use of these rules in one sentence exercises. In this concern, Teng $(2007$, p. 1) clarifies that "practitioners have demonstrated that addressing sentence level grammar and mechanics in a contextualized and systematic way does result in students' gaining greater control over the crucial systems of written language". So, the use of dictogloss technique supports this suggestion as mentioned by Nunan (2001, p. 181) who clarifies that students can "develop their grammatical awareness through inductive and deductive learning experience". He adds that dictogloss is "a technique that works extremely well for raising learners' consciousness about the workings of grammar in context". It is worth mentioning that using grammar in this way interact noticeably with writing, the reason that leads the researchers to consider the improvement of writing another variable under investigation in addition to the comprehension of meaning.

At last, this study tries to answer the following research questions:

a) Is there any impact of using dictogloss techniques on EFL college students' knowlege of grammar?

b) Is there any impact of using dictogloss techniques on EFL college students' improvement of writing? And,

c) Does the way of teaching by using dictogloss technique increases EFL college student's comprehension of meaning?

d) What are the attitudes of the participants toward using dictogloss in teaching English language? 


\subsection{Aims of the Study}

The present study aims at:

a) finding out the impact of using dictogloss technique on Iraqi EFL college students' knowledge of grammar.

b) Determining the impact of using dictogloss technique on Iraqi EFL college students' improvement of writing.

c) Determining if there is any impact of using dictogloss technique on EFL college student's comprehension of meaning.

d) Determining students' attitudes toward using dictogloss in English language teaching.

\subsection{Hypothesis}

a) There is no significant impact of using dictogloss techniques on EFL college students' knowledge of grammar.

b) There is no significant impact of using dictogloss techniques on EFL college students' improvement of writing.

c) Dictogloss technique does not significantly increase EFL college student's comprehension of meaning.

d) The students do not have positive attitudes toward using dictogloss in English language teaching.

\section{Methodology}

\subsection{Experiment Design}

Brown and Rodgers (2002, p. 210) state that "the experimental design represents the strategy which is set by the researcher to collect the necessary information and control the factors or variables which may affect this information and finally carrying out the suitable analysis to test the hypotheses of the research within a comprehensive plan". They add that "the researcher should choose the suitable experimental design which provides valid conclusions about the relationships between both independent and dependent variables".

The researchers utilize a one group experimental design in order to answer the research questions, to achieve the aims of the study and to verify the hypothesis. A group of twelve students from the first grade/ college of education for human sciences/ University of Diyala/ English Department, was chosen to represent the sample of the study for the academic year 2017-2018. The students were trained to use dictogloss technique in their grammar lectures two times a week. The researchers chose the first-grade students intentionally as their skills of English language still under construction. An achievement test of grammar was used before and after the experiment. Daily observation by the teacher and completing the reflection sheet by the participants at the end of each lecture were used to determine students' development in grammar, writing and the comprehension of meaning. Yes/No questionnaire was also used at the end of the experiment to see students' attitude towards using it. It is worth mentioning that the researchers tried their best to ensure better equivalence among the participants in order to control some of the variables that may affect the results of the experiment. Therefore, the following variables have been controlled; the age of the participants and the academic level of the parents.

\subsection{The Experimental Application}

The experiment of the study started on the $4^{\text {th }}$ of March 2018 and lasted for six weeks to end up on $11^{\text {th }}$ of April 2018. The lectures have been arranged according to the table of the students, two times a week. The researchers used twelve authentic texts from Elbaum's book "Grammar in Context" (2005). Each passage focuses on a specific rule of grammar. When the text is too long, the teacher cut it to be suitable to the time of the lecture and the level of the students. The rule of grammar and the related contexts that used in this experiment were:

- The present tense of the verb be; prepositions of place, this, that, these, those. The context: college life. (p. 2)

- The simple present tense. The context: The U.S. Government. (p. 42)

- Frequency words. The context: American holidays. (p. 78)

- Singular and plural. The context: Americans and where they live. (p. 102)

- Possession. The context: Families and names. (p. 131)

- The present continuous tense. The context: Observation about American life. (p. 159)

- Future tense. The context: Planning for Weddings. (p. 190) 
- The simple past tense. The context: Flying. (p. 224)

- Infinitives. The context: Smart shopping. (p. 264)

- Count and noncount nouns. The context: Nutrition and health. (p. 308)

- Adjectives. The context: Great woman. (p. 334)

- Comparatives; superlatives. The context: U.S. geography. (p. 356)

The teacher begins by dividing the students into three groups, each of which of four. The main steps of this process were:

1) The first step

In this step, the teacher begins to prepare students by focusing on the passage itself. She wrote the title on the board and clarified the rule of grammar that will receive the focus. After this process, the teacher asked the students to brainstorm the ideas concerning the content of the passage in order to make a kind of prediction before a dictation process. A kind of discussion occurs between the teacher and the students to make sure that they know what is required from them to do.

2) The second step

At this stage, the teacher begun to read a passage at somehow slow rate and the students begun to take notes concerning the target text. The number of reading processes determined according to students' understanding to the text. The purposeful listening is very necessary at this stage because it represents a key to deliver clear input to the students.

\section{3) The third step}

This step represents the process of reconstruction of the text individually. Each student writes a text depending on the registered notes. A kind of sharing occurs at that time when the students exchanged notes and ideas. The recreation process required students to pay attention to write approximately similar to the original text and to use correct rules of grammar.

4) The fourth step

After completing the texts, the students started to check their writing by comparing it to the original one and then with their peers during group work section. The groups consisted of four students for each. This stage breaks the ice among students as they begin to cooperate and collaborate actively in order to be the winner. The spirit of competition, this way of teaching creates, makes the students energetic and enthusiastic. Their class engagement also enriched as they exchanged the right answers. Teacher role demonstrated when she guided and controlled the students writing and self-assess process. When the teacher finished controlling the correction process of all student' performance, they begin to complete the reflection sheet (see table 1) that supposed to show their level of grammar, writing, and the comprehension of meaning and to clarify their development in next lectures by comparing these sheets. This step of decision making helps students to be autonomous learners. When a new lecture begins, the teacher makes a kind of review by using the same previous reflection sheet in order to reinforce the retention of information by helping the students to remember their errors and to work on them.

\subsection{Instruments}

The first instrument was an achievement test of grammar that applied before and after the experiment. The students supposed to study these roles of grammar traditionally in the first semester. The test consists of two questions; the first one has 36 multiple choice items, each three assess a specific role. The second is a text that has many dashes to be completed by students by providing the suitable answer.

The second instrument was the reflection sheet (table 1) constructed by the researchers, which was used as a self-assess technique to check statistically students' development from lecture to lecture and to let students evaluate themselves as a step towards students-centered learning. 
Table 1 . The daily reflection sheet

\begin{tabular}{lll}
\hline $\begin{array}{l}\text { The first lecture } \\
\text { The date: }\end{array}$ & \\
The title of the text: & & \\
\hline grammar & writing & comprehension of meaning \\
Total number of errors in grammar & Total number of errors in writing & $\begin{array}{l}\text { Total understanding of the text's idea } \\
\text { poor gery good }\end{array}$ \\
& & good The totally new words \\
\hline
\end{tabular}

The third instrument was the yes/no questionnaire (see table 2) that completed by the students at the end of the experiment to determine their attitudes toward using dictogloss technique. It consists of seven dichotomous questions and three choices (yes, partially, no). The questionnaire constructed by the researchers depending on the literature of the subject and the variables of the study then it exposes to a certain of experts to determine its face validity.

Table 2. The yes/ no questionnaire

\begin{tabular}{llll}
\hline The questions & Yes & Partially & NO \\
\hline Do you think that your language skills benefited from using dictogloss? & 8 & 3 & 1 \\
Do you think that the use of dictogloss was effective in teaching grammar? & 9 & 2 & 1 \\
Do you prefer to turn all traditional grammar lessons into dictogloss? & 9 & 1 & 2 \\
Do you think that the use of dictogloss technique improved your writing positively? & 10 & 2 & 0 \\
Is the use of contexts help in raising your knowledge of vocabulary and the comprehension of meaning? & 10 & 2 & 0 \\
Do you think that sharing and cooperation with peers affect your language use? & 11 & 1 & 0 \\
Do you feel motivated towards the use of dictogloss in language teaching? & 9 & 2 & 1 \\
\hline
\end{tabular}

\section{Results and Discussion}

\subsection{Results Related to the First Hypothesis}

In order to achieve the aim of the study, the researchers depend on a pre-posttest design. Using the t-test for one sample reveals that the mean score of the pre-test is 33.37 and that of the post-test is 43.30 . The computed $\mathrm{t}$-value is higher than the table one. This means that there is a statistically significant difference between the two tests in favor of the post-test.

As far as the results of the reflection sheet are concerned, three dimensions were measured by using it. The first one is grammar. When the students start correcting themselves in comparison with their peers and under the supervision of the teacher, they determine their errors then they classify the errors into errors that related to the rule under discussion which is related to the current context of the lesson, and other grammatical errors. The researchers discovered that students' performance improved gradually as they proceed in the experiment. They insist on correcting their errors by knowing the right form during sharing step. The results show that the mean score of the rule under discussion is 30 which is less than the mean score of the other types of grammatical errors which is 40 . This result related to the first three weeks of the experiment where the students are still training to use dictogloss and their experience to use it still not mature. In the second part of the experiment, in the last three weeks, and as a result of improving their ability to use dictogloss, students' engagement and enthusiasm increased and in turn their knowledge of grammar improved significantly. This affects students' level in grammar notably when the mean score of the rule under discussion reads only 10 and the other grammatical errors 15 . These results add an important variable that affects the use of dictogloss in lessons which is time. This means that teachers should not give judgment from the first or second lessons.

As a result, the first hypothesis rejected. This result explores the positive role of dictogloss technique on students' performance in grammar.

Table 3. The results of students' performance of grammar in reflection sheet

\begin{tabular}{lll}
\hline Students' performance in grammar & The mean of the total number of errors & The mean of the errors of the rule under discussion \\
\hline The first three weeks & 30 & 40 \\
The second three weeks & 10 & 15 \\
\hline
\end{tabular}




\subsection{Results Related to the Second Hypothesis}

Assessing writing process according to this study depends on two things; the total number of errors and the types of these errors. The researchers compare students' performance in writing in the first and second part of the experiment to check student's development. In the first six lectures, students' mean score of the total number of errors was 63 and the mean scores of the types of the repeated errors mentioned were; 10 percent of capitalization, 30 percent of organization/ order, 8 percent of punctuation, and 15 percent of spelling.

In the second six lectures, the students showed mature level of writing as they begin to avoid these errors. They rarely appear in their writing. The mean score of the errors noticed were as the following; the total number of errors was 23 and the mean scores of the types of the repeated errors mentioned were; 3 percent of capitalization, 10 percent of organization/ order, 2 percent of punctuation, and 8 percent of spelling. These results clarify that there is a significant development in students writing due to the use of dictogloss technique with its complementary steps. This result means that the second hypothesis rejected.

Table 4. The results of the improvement of writing in reflection sheet

\begin{tabular}{llllll}
\hline $\begin{array}{l}\text { Students' performance in } \\
\text { writing }\end{array}$ & $\begin{array}{l}\text { The mean of the total number } \\
\text { of errors }\end{array}$ & $\begin{array}{l}\text { Types of errors } \\
\text { capitalization }\end{array}$ & organization/ order & punctuation & spelling \\
\hline The first three weeks & 63 & 10 & 30 & 8 & 15 \\
The second three weeks & 23 & 3 & 10 & 2 & 8 \\
\hline
\end{tabular}

\subsection{Results Related to the Third Hypothesis}

The comprehension of meaning is the third variable that measured in the reflection sheet. It divided into two dimensions; the first one is the comprehension of the main idea of the text. The students answer according to three scales; poor, good, and very good. In the second dimension the students write the totally new words. The results of the first six lectures show that the percentage of the students that pick up the main idea of the text was $60 \%$ of the very good, $31 \%$ of the good and $9 \%$ of poor and that each one of them wrote at least ten new words. In the second part of the experiment, the results improved by rising the percentage of the experiment into $78 \%$ of the very good, $18 \%$ of the good and $4 \%$ of poor and that the number of new words vary between three to seven for each student. This result clearly shows the significant positive impact of using dictogloss in the comprehension of meaning, so the third hypothesis rejected.

Table 5. The results of the comprehension of meaning in reflection sheet

\begin{tabular}{lllll}
\hline Students' comprehension of meaning & \multicolumn{2}{l}{ Understanding of the main idea } & The totally new words \\
& v. good & good & poor & \\
\hline The first three weeks & $60 \%$ & $31 \%$ & $9 \%$ & At least 10 new words \\
The second three weeks & $78 \%$ & $18 \%$ & $4 \%$ & $3-7$ new words \\
\hline
\end{tabular}

The use of reflection sheet in all its three dimensions proves that students' level improved significantly in grammar, writing and the comprehension of meaning due to the multi-skill nature of this technique and the participation of more than one skill in the students' performance.

\subsection{Results Related to the Fourth Hypothesis}

In order to identify students' attitudes toward using dictogloss in teaching English, a questionnaire was constructed by the researchers (table 2). The questionnaire was applied on the students after completing the experiment to see their attitudes and impressions towards the use of dictogloss and whether they prefer using it in future teaching or not. Students' results (see table 2) show that the (yes) scale takes $75 \%$. This means that most of students have positive attitudes toward using dictogloss and agreed on the benefit of it in enriching the whole process of teaching in all its aspects and its positive impact on improving students' knowledge of grammar, writing, and the comprehension of meaning. Thus, the fourth hypothesis also rejected.

\subsection{Results Related to the Teachers Observation}

Teacher observation is an active way to see other variables that affected by using the dictogloss technique and they do not measure by the tools of the study. Based on what is stated by Nunan and Baily (2009:259) that "manual data collection can be either open-ended or they can be constrained by an observation schedule". As a result, the researchers noticed the following; purposeful listening can have a very active role in teaching, 
students' interaction improved notably during the experiment, students' risk-taking increased specifically in the discussion step, students' engagement and enthusiasm are noticed as the students become responsible for their work, insistence to gain the right form, dealt with the lesson as a game that creates a favorable atmosphere in class, and positive spirit of competition was existed which lead to improve the results of the reflection sheet gradually.

\section{Conclusions}

The main conclusions of this study can be stated in relation to the variables under investigation which are grammar, writing and the comprehension of meaning. Students' knowledge of grammar is improved significantly according to the results of the measurement tools used in this study. The use of context in teaching grammar and the subsequent steps of dictogloss affect students' knowledge of grammar positively to a large extent. Students' writing improved notably as they determine their mistakes by themselves and trying to avoid them in next lectures. The use of the reflection sheet helps them to know their errors and to work on them. The use of context leads to the accumulation of vocabulary and to exploit them in the right way that enhances students' comprehension of meaning and the overall knowledge of vocabulary. The students can not finish its steps without thinking of meaning and the use of vocabulary.

Other variables are improved as a result of applying dictogloss in teaching such as students' interaction, risk-taking, engagement, enthusiasm, thinking skills, note taking and autonomy. The use of dictogloss technique with its four stages help to create atmosphere where all the four skills are cooperated, benefited and sharpened. It worth mentioning that time factor is very crucial in using dictogloss technique as clarified by this study. The results of using it can be seen after a period of time as a result of training and exercise.

This study comes in line with what concluded by Dewi (2017), Stewart et al., (2014), Smith (2012) and Mackenzie (2011). As a final remark, the positive impact of the use of dictogloss in teaching comes as a result of its complementary steps that change the mode of teaching in class and create favorable atmosphere in learning.

\section{Instructional Implications and Recommendations}

The main instructional implications and recommendations of this study centered on how teachers can break the ice in the class by using such innovative, multi-skill activities as dictogloss. This way of teaching can operate more than one skill at the same time. It leads students to listen, think, write, construct, and cooperate, all in one activity. The use of dictogloss in language teaching is preferable as it can activate students' innate knowledge of language by the process of meaning-making they pass. Teachers are advised to use this technique diagnostically. This occurs by determining students' needs and linguistic levels so as to put the suitable remedial work. The nature of dictogloss steps activates the use of grouping in class. So, it is a golden chance for teachers to promote the ideas of sharing and cooperation among students without raising sensitivities. Teachers can also benefit from the use of dictogloss to save time in testing as it considers as a multi-skill test. So, he/she can test more than one skill at the same time.

This study done in an EFL context of teaching English, so the results of the study may be limited to that context. The researchers recommend applying it with other various contexts and with other variables in order to get more reliable results.

\section{References}

Brown, D. (2001). Teaching by Principles. Longman: San Francisco State University.

Brown, J. D., \& Rodgers, T. S. (2002). Doing Second Language Research. Oxford: Oxford University Press.

Dewi, E. (2017). Improving Students Grammar Using Dictogloss. English Education Journal, 8(3), 352-366.

Elbaum, S. (2005). Grammar in Context. Thomson Heinle: Bosten.

Freeman, D. L., \& Anderson, M. (2011). Techniques \& Principles in Language Teaching. Oxford: Oxford University Press.

Johnson, K., \& Johnson, H. (1999). Encyclopedic Dictionary of Applied Linguistics. Malden: Blackwell Publishers Ltd. https://doi.org/10.1111/b.9780631214823.1999.x

Lin, H. (2010). A Case Study: An ESL Teacher's Beliefs and Classroom Practices in Grammar Instruction. Unpublished Thesis, Kent State University, Kent, Ohio, USA.

Mackenzie, A. (2011). Dictogloss Tasks to Promote Cooperative Learning and Vocabulary Acquisition. Journal of Business Administration Toyo University, 135-143.

Nunan, D. (2001). Second Language Teaching and Learning. Heinle \& Heinle Publishers: Boston. 
Nunan, D., \& Bailey, K. (2009). Exploring Second Language Classroom Research. Bosten: Heinle.

Scrivener, J. (2011). Learning Teaching. Macmillan: Oxford.

Smith, K. (2012). Dictogloss: A Multi-Skill Task for Accuracy in Writing Through Cooperative Learning. Teachers Helping Teachers. The Proceedings of 2011 conferences, Seminars and workshops. Laos American College, National University of Laos, Vientiane, Laos.

Stewart, B., Silva, L., \& González, J. (2014). Integrating Language Skills through a Dictogloss Procedure. English Teaching Forum. from https://americanenglish.state.gov/files/ae/resource_files/etf_52_2_12-19_and_35.pdf

Teng, S. F.-C. (2007). A Reference Grammar of Puyuma, an Austronesian Language of Taiwan. Unpublished dissertation, Pacific Linguistics, Research School of Pacific and Asian Studies, Australian National University.

Wajnryb, R. (1990). Grammar dictation. Oxford: Oxford University Press.

\section{Copyrights}

Copyright for this article is retained by the author, with first publication rights granted to the journal.

This is an open-access article distributed under the terms and conditions of the Creative Commons Attribution license (http://creativecommons.org/licenses/by/4.0/). 